\title{
Association between environmental factors and COVID-19 in Shanghai, China
}

\author{
Yuxia $\mathrm{Ma}^{1} \cdot$ Bowen Cheng $^{1} \cdot$ Jiahui Shen $^{1} \cdot$ Hang Wang $^{1} \cdot$ Fengliu Feng $^{1} \cdot$ Yifan Zhang $^{1} \cdot$ Haoran Jiao $^{1}$
}

Received: 25 November 2020 / Accepted: 5 April 2021 / Published online: 15 April 2021

(C) The Author(s), under exclusive licence to Springer-Verlag GmbH Germany, part of Springer Nature 2021

\begin{abstract}
The outbreak of coronavirus disease 2019 (COVID-19) continues to spread worldwide and has led to recession, rising unemployment, and the collapse of the health-care system. The aim of this study was to explore the exposure-response relationship between daily confirmed COVID-19 cases and environmental factors. We used a time-series generalized additive model (GAM) to investigate the short-term association between COVID-19 and environmental factors by using daily meteorological elements, air pollutant concentration, and daily confirmed COVID-19 cases from January 21, 2020, to February 29, 2020, in Shanghai, China. We observed significant negative associations between daily confirmed COVID-19 cases and mean temperature ( $\left.T_{\text {ave }}\right)$, temperature humidity index (THI), and index of wind effect (K), whereas air quality index (AQI), $\mathrm{PM}_{2.5}, \mathrm{PM}_{10} \mathrm{NO}_{2}$, and $\mathrm{SO}_{2}$ were significantly associated with the increase in daily confirmed COVID-19 cases. A $1{ }^{\circ} \mathrm{C}$ increase in $\mathrm{T}_{\text {ave, }}$, one-unit increase in THI, and 10-unit increase in $\mathrm{K}$ (lag 0-7 days) were associated with 4.7, 1.8, and $1.6 \%$ decrease in daily confirmed cases, respectively. Daily $\mathrm{T}_{\text {ave }}$, THI, K, $\mathrm{PM}_{10}$, and $\mathrm{SO}_{2}$ had significant lag and persistence (lag 0-7 days), whereas the lag and persistence of AQI, $\mathrm{PM}_{2.5}$, and $\mathrm{NO}_{2}$ were significant at both lag $0-7$ and $0-14$ days. A $10-\mu \mathrm{g} / \mathrm{m}^{3}$ increase in $\mathrm{PM}_{10}$ and $1-\mu \mathrm{g} /$ $\mathrm{m}^{3}$ increase in $\mathrm{SO}_{2}$ was associated with 13.9 and $5.7 \%$ increase in daily confirmed cases at lag 0-7 days, respectively, whereas a 10-unit increase in AQI and a $10-\mu \mathrm{g} / \mathrm{m}^{3}$ increase in $\mathrm{PM}_{2.5}$ and $\mathrm{NO}_{2}$ were associated with 7.9, 7.8, and $10.1 \%$ increase in daily confirmed cases at lag 0-14 days, respectively. Our findings have important implications for public health in the city of Shanghai.
\end{abstract}

Keywords Air pollution · COVID-19 · Environmental factors

\section{Highlights}

1. The exposure-response relationship between COVID-19 and $\mathrm{T}_{\text {ave }}$ was positive when $\mathrm{T}<5{ }^{\circ} \mathrm{C}$ and became negative when $5{ }^{\circ} \mathrm{C}<\mathrm{T}<15^{\circ} \mathrm{C}$.

2. Temperature humidity index (THI) and index of wind effect $(\mathrm{K})$ showed significant negative relationships with the transmission of COVID-19.

3. Air pollution was significantly positive associated with daily confirmed COVID-19 cases.

Yuxia Ma and Bowen Cheng contributed equally to this work as co-first authors

Responsible Editor: Lotfi Aleya

Yuxia Ma

mayuxia07@1zu.edu.cn

1 College of Atmospheric Sciences, Key Laboratory of Semi-Arid Climate Change, Ministry of Education, Lanzhou University, Lanzhou 730000, China

\section{Introduction}

In late 2019, a novel coronavirus called severe acute respiratory syndrome coronavirus 2 (SARS-CoV-2), which causes coronavirus disease 2019 (COVID-19), spread globally (Xu et al. 2020a, b; Sohrabi et al. 2020). The highly infectious nature and long incubation period of the virus make it a serious threat to global health.

COVID-19 can rapidly spread through person-to-person transmission (Chen et al. 2020; Liu et al. 2020a, b), and the virus can cause serious fever, cough, headache, and respiratory problems (Waldman et al. 2020). COVID-19 has caused a global economic decline, an increase in the unemployment rate, and the collapse of health-care systems (Mollalo et al. 2020; Sarkodie and Owusu 2020). On August 27, 2020, the World Health Organization (WHO) reported more than $24,021,218$ confirmed cases and 821,462 deaths globally.

Studies have shown that meteorological elements are crucial for the spread, growth, and survival of viruses. For example, high temperature, low wind speed, and low relative 
humidity have been positively associated with the Middle East respiratory syndrome coronavirus (MERS-CoV) (Altamimi and Ahmed 2020; Amuakwa-Mensah et al. 2017). Pediatric influenza was revealed to be positively associated with high concentrations of ambient $\mathrm{PM}_{10}$ (relative risk [RR]: 1.11; 95\% confidence interval [CI]: 1.10-1.13) and $\mathrm{O}_{3}$ (RR: $1.28 ; 95 \%$ CI: 1.25-1.31) in Brisbane, Australia (Xu et al. 2013). Studies have reported that $60 \%$ of confirmed COVID-19 cases were found where optimum air temperature ranged from 5 to $15^{\circ} \mathrm{C}$ (Gunthe et al. 2020; Huang et al. 2020). Notari (2021) suggested that the growth rate of confirmed COVID-19 cases would decrease due to lockdown policies and warm weather. Cole et al. (2020) indicated that a $1-\mu \mathrm{g} / \mathrm{m}^{3}$ increase in the $\mathrm{PM}_{2.5}$ concentration was associated with 9.4 more daily confirmed COVID-19 cases. Peto et al. (2020) found that environmental elements are vital for viral transmission.

Shanghai, China $\left(121^{\circ} 47^{\prime} \mathrm{E}, 31^{\circ} 23^{\prime} \mathrm{N}\right)$, has been seriously affected by COVID-19 and continues to import cases daily. In this study, we assessed the effect of environmental factors and the biometeorological index on COVID-19. Moreover, we conducted a 14-day lag study to investigate the effect of the lag and persistence of environmental factors on COVID-19 in Shanghai. Our findings have city-wide implications for public health and provide insights into the effect of environmental factors on COVID-19 transmission.

\section{Data and methods}

The time-series data included daily meteorological elements, air quality index (AQI), air pollutant concentrations, and number of daily confirmed COVID-19 cases in Shanghai, China, from January 21, 2020, to February 29, 2020.

Meteorological data were collected daily by the China Meteorological Data Network (http://data.cma.cn), including mean temperature $\left(\mathrm{T}_{\mathrm{ave}},{ }^{\circ} \mathrm{C}\right)$, relative humidity $(\mathrm{RH}, \%)$, air pressure $(\mathrm{P}, \mathrm{hPa})$, wind speed $(\mathrm{V}, \mathrm{m} / \mathrm{s})$, and sunshine duration $(\mathrm{H}, \mathrm{h})$. Daily air quality data, namely, the AQI and mean concentrations of $\mathrm{NO}_{2}, \mathrm{SO}_{2}, \mathrm{PM}_{2.5}, \mathrm{PM}_{10}, \mathrm{CO}$, and $\mathrm{O}_{3}-8 \mathrm{~h}$, were obtained from the China National Environmental Monitoring Center. After the SARS epidemic, China established a reporting system for public health emergencies and infectious diseases. Data on daily confirmed COVID-19 cases were obtained from the National Health Commission in Shanghai.

The generalized additive model (GAM) is widely used in similar studies. We used the GAM in combination with conditional Poisson regression to assess the effect on daily confirmed COVID-19 cases. Long-term trends, latitude factors, air quality, and meteorological factors, including relative humidity, air pressure, wind speed, and sunshine duration, were adjusted as confounders. The basic model is described below:

$$
\begin{gathered}
\log \left[E\left(Y_{i}\right)\right]=\alpha+D O W+\beta X_{i}+\text { lat }+s(\text { time }, d f)+s\left(A Q I_{i}, d f\right)+s\left(H_{i}, d f\right) \\
+s\left(P_{i}, d f\right)+s\left(V_{i}, d f\right)+s\left(Q_{i}, d f\right)
\end{gathered}
$$

Here, $Y_{i}$ is the number of daily confirmed COVID-19 cases, and $\mathrm{E}\left(\mathrm{Y}_{\mathrm{i}}\right)$ is the expected confirmed cases on day $\mathrm{i} ; \alpha$ is the intercept; DOW is the day of the week; $\beta$ denotes the exposure-response coefficient; $\mathrm{s}$ is a regression spline function; df indicates the degree of freedom; time denotes the days of calendar date; and $\mathrm{X}_{\mathrm{i}}, \mathrm{AQI}_{\mathrm{i}}, \mathrm{H}_{\mathrm{i}}, \mathrm{P}_{\mathrm{i}}, \mathrm{V}_{\mathrm{i}}$, and $\mathrm{Q}_{\mathrm{i}}$ represent the explanatory variables, AQI, sunshine duration, average air pressure, average wind speed, and relative humidity on day i, respectively.

The temperature humidity index (THI) and index of wind effect $(\mathrm{K})$ were calculated as follows:

$$
\begin{aligned}
& T H I=T_{d}-0.55 *(1-f) *\left(T_{d}-58\right) \\
& K=-(10 \sqrt{V}+10.45-V) *(33-T)+8.55 * H
\end{aligned}
$$

Here, $\mathrm{T}_{\mathrm{d}}, \mathrm{f}, \mathrm{V}, \mathrm{T}$, and $\mathrm{H}$ refer to Fahrenheit, relative humidity, average wind speed, mean temperature, and sunshine duration, respectively. The THI is a biometeorological index, which is based on heat exchanged between the human body and atmosphere. $\mathrm{K}$ is the degree of warmth of the naked skin under the effect of temperature and wind speed (Yan et al. 2009). The two indexes were divided into nine levels (Table 1).

We selected $\mathrm{T}_{\text {ave }}$, THI, $\mathrm{K}, \mathrm{AQI}, \mathrm{PM}_{2.5}, \mathrm{PM}_{10}, \mathrm{NO}_{2}$, and $\mathrm{SO}_{2}$ as explanatory variables in eight models to examine their effects on daily confirmed COVID-19 cases. The Akaike information criterion (AIC) is a statistical method to estimate degrees of complexity and fit. We adjusted each degree of freedom to get the smallest AIC. Moreover, we used the results of the models to calculate the RR and cumulative RR to further investigate the lag and persistent effects of environmental factors on COVID-19.

Table 1 Standard range of temperature humidity index and index of wind effect

\begin{tabular}{lll}
\hline & THI & $\mathrm{K}$ \\
\hline Extremely cold & $<40$ & $<-1200$ \\
Cold & $40-45$ & -1000 to -1200 \\
Very cool & $45-55$ & -800 to -1000 \\
Cool & $55-60$ & -600 to -800 \\
Comfort & $60-65$ & -300 to -600 \\
Warm & $65-70$ & -200 to -300 \\
Very warm & $70-75$ & -50 to -200 \\
Hot & $75-80$ & 80 to -50 \\
Extremely hot & $>80$ & $>80$ \\
\hline
\end{tabular}


The National Health Commission of China has reported that COVID-19 has an incubation period from 1 to 14 days, which is consistent with the findings of other reports. Models with a 14-day lag function were used to investigate the lag effect of environmental factors on COVID-19. The models were implemented in R statistical software by using the "mgcv" package. Statistically significant difference was set at $p<0.05$.

\section{Results}

Table 2 summarizes the descriptive statistics of daily confirmed COVID-19 cases, meteorological elements, and air pollutant concentrations. A total of 337 confirmed COVID19 cases, averaging 8 cases per day, were reported from January 21,2020 , to February 29, 2020. The daily average concentrations of AQI, $\mathrm{SO}_{2}, \mathrm{PM}_{2.5}, \mathrm{PM}_{10}, \mathrm{NO}_{2}$, and $\mathrm{O}_{3}$ were $60.2,5.7,38.4,36.7,29.0$, and $86.3 \mu \mathrm{g} / \mathrm{m}^{3}$, respectively. The daily average temperature, relative humidity, air pressure, and wind speed were $8.2{ }^{\circ} \mathrm{C}, 77.8 \%, 1025.0 \mathrm{hPa}$, and $1.2 \mathrm{~m} / \mathrm{s}$, respectively.

Table 3 shows the Pearson correlations of air pollutants and meteorological elements in Shanghai. The AQI was positively correlated with other air pollutants, especially $\mathrm{PM}_{2.5}(\mathrm{r}=0.97$, $p<0.05$ ). The relative humidity had a significantly positive correlation with $\mathrm{T}_{\text {ave }}$ and negative correlations with $\mathrm{SO}_{2}$, $\mathrm{PM}_{10}$, and $\mathrm{O}_{3}$. Air pressure positively correlated with $\mathrm{O}_{3}$ and negatively with $\mathrm{T}_{\text {ave }}$ and relative humidity.

$\mathrm{T}_{\text {ave }}$, THI, K, AQI, $\mathrm{PM}_{2.5}, \mathrm{PM}_{10}, \mathrm{NO}_{2}$, and $\mathrm{SO}_{2}$ greatly affected daily confirmed COVID-19 cases (Table 4). The eight factors were statistically significant as explanatory variables when $p<0.05$. The explanation rates of $\mathrm{T}_{\text {ave }}$, THI, $\mathrm{K}$, AQI, $\mathrm{PM}_{2.5}, \mathrm{PM}_{10}, \mathrm{NO}_{2}$, and $\mathrm{SO}_{2}$ to the daily confirmed

Table 2 Descriptive statistics for daily confirmed coronavirus disease 2019 cases, air pollutant concentrations, and meteorological elements in Shanghai

\begin{tabular}{lllll}
\hline & Mean $(\mathrm{SD})$ & Min & Max & IQR \\
\hline Daily confirmed cases & 8 & 0 & 34 & 6 \\
$\mathrm{AQI}$ & 60.2 & 30.0 & 128.0 & 12.9 \\
$\mathrm{SO}_{2}\left(\mu \mathrm{g} / \mathrm{m}^{3}\right)$ & 5.7 & 3.0 & 9.0 & 0.6 \\
$\mathrm{PM}_{2.5}\left(\mu \mathrm{g} / \mathrm{m}^{3}\right)$ & 38.4 & 13.0 & 97.0 & 13.1 \\
$\mathrm{PM}_{10}\left(\mu \mathrm{g} / \mathrm{m}^{3}\right)$ & 36.7 & 7.0 & 96.0 & 12.1 \\
$\mathrm{NO}_{2}\left(\mu \mathrm{g} / \mathrm{m}^{3}\right)$ & 29.0 & 15.0 & 57.0 & 6.3 \\
$\mathrm{O}_{3}\left(\mu \mathrm{g} / \mathrm{m}^{3}\right)$ & 86.3 & 48.0 & 129.0 & 10.3 \\
$\mathrm{~T}\left({ }^{\circ} \mathrm{C}\right)$ & 8.2 & 2.2 & 17.5 & 1.8 \\
$\mathrm{RH}(\%)$ & 77.8 & 44.0 & 96.0 & 9.4 \\
$\mathrm{P}(\mathrm{hPa})$ & 1025.0 & 1016.0 & 1032.0 & 2.0 \\
$\mathrm{~V}(\mathrm{~m} / \mathrm{s})$ & 2.5 & 1.1 & 4.4 & 0.7 \\
\hline
\end{tabular}

COVID-19 cases were $31.1,36.4,22.2,13.1,7.8,4.7,4.8 \%$, and $6.7 \%$, respectively. Adjusted $\mathrm{R}^{2}$ indicated the fitting degree of the model. Of the eight explanatory factors, the THI had excellent fitting degree of the model. The function is a linear (nonlinear) equation when the estimated degree of freedom (Edf) is (is not) equal to 1 . The Edf values of $\mathrm{T}_{\text {ave }}, \mathrm{THI}$, AQI, $\mathrm{PM}_{2.5}, \mathrm{PM}_{10}, \mathrm{NO}_{2}$, and $\mathrm{SO}_{2}$ were greater than 1 , suggesting that the relationship between environmental factors and daily confirmed COVID-19 cases was significantly nonlinear. The Edf value of $\mathrm{K}$ was close to 1, suggesting that the relationship between $\mathrm{K}$ and daily confirmed COVID-19 cases was significantly linear. The effects of environmental factors on COVID-19 cases determined using GAM models are shown in Fig. 1.

Figure 1 indicates the exposure-response relationship between $\mathrm{T}_{\text {ave, }}$ THI, K, AQI, $\mathrm{PM}_{2.5}, \mathrm{PM}_{10}, \mathrm{NO}_{2}$, and $\mathrm{SO}_{2}$ and daily confirmed COVID-19 cases in Shanghai. $\mathrm{T}_{\text {ave }}$ exhibited an S-shaped exposure-response relationship with COVID-19. The relationship curve had a slowly increasing trend in the range of $\mathrm{T}<5{ }^{\circ} \mathrm{C}$, which decreased when $5{ }^{\circ} \mathrm{C}<\mathrm{T}<15^{\circ} \mathrm{C}$. The relationship curve of THI and COVID-19 declined in the range of THI $<56$ and then became flat when $\mathrm{THI}>56$. We found a significantly linear decreasing relationship between $\mathrm{K}$ and COVID-19, indicating that the daily confirmed COVID19 cases would have a negative relationship with $\mathrm{K}$. The relationship curve for AQI, $\mathrm{PM}_{2.5}, \mathrm{PM}_{10}$, and $\mathrm{SO}_{2}$ had a slowly increasing trend, suggesting positive relationships between AQI, $\mathrm{PM}_{2.5}, \mathrm{PM}_{10}$, and $\mathrm{SO}_{2}$ and COVID-19. We found a negative relationship between COVID-19 and $\mathrm{NO}_{2}$ when $\mathrm{NO}_{2}<40 \mu \mathrm{g} / \mathrm{m}^{3}$ and became positive when $\mathrm{NO}_{2}>40 \mu \mathrm{g} / \mathrm{m}^{3}$.

Figure 2 demonstrates the RR and cumulative RR of daily confirmed COVID-19 cases with a unit increase in $\mathrm{T}_{\text {ave }}$, THI, $\mathrm{K}, \mathrm{AQI}, \mathrm{PM}_{2.5}, \mathrm{PM}_{10}, \mathrm{NO}_{2}$, and $\mathrm{SO}_{2}$ in Shanghai. The effects of $\mathrm{T}_{\text {ave }}, \mathrm{THI}$, and $\mathrm{K}$ on daily confirmed COVID-19 cases were negative at lag 3-6 days, 4-6 days, and 5-6 days, respectively. The cumulative RRs (lag 0-7) between $\mathrm{T}_{\text {ave }}$, THI, and $\mathrm{K}$ and daily confirmed COVID-19 cases were 0.953 (95\% CI: 0.791-1.166), 0.982 (95\% CI: 0.881-1.096), and 0.984 (95\% CI: 0.932-1.039), respectively; the cumulative RRs were not significant at lag 0-14 days. Regarding air pollution, the effects on daily confirmed COVID-19 cases were significant at lag 2-6 days for AQI, $\mathrm{PM}_{2.5}$, and $\mathrm{PM}_{10}$; at lag 0-3 days for $\mathrm{NO}_{2}$; and at lag 1-6 days for $\mathrm{SO}_{2}$, with the highest RRs of 1.031 (95\% CI: 0.974-1.092), 1.039 (95\% CI: 0.971-1.112), 1.060 (95\% CI: $0.968-1.161), 1.142$ (95\% CI: 0.962-1.356), and 1.113 (95\% CI: 0.999-1.239), respectively. The cumulative RRs between $\mathrm{AQI}, \mathrm{PM}_{2.5}$, and $\mathrm{NO}_{2}$ and daily confirmed COVID-19 cases were 1.232 (95\% CI: 1.040-1.416), 1.101 (95\% CI: $1.034-1.210)$, and 1.109 (95\% CI: 0.923-1.325) at lag 0-7 days and were significant at lag 0-14 days, with cumulative RRs of 1.079 (95\% CI: 0.934-1.167), 1.078 (95\% CI: 0.976-1.223), and 1.101 (95\% CI: 1.034-1.210), respectively. The cumulative RRs between $\mathrm{PM}_{10}$ and $\mathrm{SO}_{2}$ and daily 
Table 3 Pearson correlations of air pollutants and meteorological elements in Shanghai

\begin{tabular}{|c|c|c|c|c|c|c|c|c|c|c|}
\hline & AQI & $\mathrm{SO}_{2}$ & $\mathrm{PM}_{2.5}$ & $\mathrm{PM}_{10}$ & $\mathrm{NO}_{2}$ & $\mathrm{O}_{3}$ & $\mathrm{~T}_{\mathrm{ave}}$ & RH & $\mathrm{P}$ & V \\
\hline AQI & 1.00 & & & & & & & & & \\
\hline $\mathrm{SO}_{2}$ & $0.44 *$ & 1.00 & & & & & & & & \\
\hline $\mathrm{PM}_{2.5}$ & $0.97 *$ & $0.41 *$ & 1.00 & & & & & & & \\
\hline $\mathrm{PM}_{10}$ & $0.80^{*}$ & $0.57 *$ & $0.78^{*}$ & 1.00 & & & & & & \\
\hline $\mathrm{NO}_{2}$ & $0.51 *$ & 0.08 & $0.50^{*}$ & 0.21 & 1.00 & & & & & \\
\hline $\mathrm{O}_{3}$ & $0.37 *$ & $0.56^{*}$ & 0.27 & $0.59 *$ & 0.03 & 1.00 & & & & \\
\hline $\mathrm{T}_{\mathrm{ave}}$ & -0.3 & -0.21 & -0.04 & 0.09 & 0.22 & 0.02 & 1.00 & & & \\
\hline RH & -.01 & $-0.71 *$ & -0.03 & $-0.37 *$ & 0.26 & $-0.55^{*}$ & $0.34 *$ & 1.00 & & \\
\hline $\mathrm{P}$ & -0.06 & 0.19 & -0.11 & 0.11 & -0.21 & $0.40^{*}$ & $-0.56^{*}$ & $-0.49 *$ & 1.00 & \\
\hline V & -0.24 & 0.01 & -0.21 & -0.21 & $-0.62 *$ & -0.08 & -0.13 & -0.15 & -0.04 & 1.00 \\
\hline
\end{tabular}

$* p<0.05$

confirmed COVID-19 cases were 1.139 (95\% CI: $1.005-$ 1.314 ) and 1.057 (95\% CI: 0.954-1.164) at lag 0-7 days, respectively, but not significant at lag $0-14$ days. Thus, $T_{\text {ave }}$, THI, and $\mathrm{K}$ had a significantly negative effect on daily confirmed COVID-19 cases at lag 4-6 days and the cumulative effects were significant at lag 0-7 days. Daily confirmed COVID-19 cases were significantly associated with AQI, $\mathrm{PM}_{2.5}$, and $\mathrm{PM}_{10}$ at lag 2-6 days; $\mathrm{NO}_{2}$ at lag 0-3 days; and $\mathrm{SO}_{2}$ at lag 1-6 days. The cumulative effects of AQI, $\mathrm{PM}_{2.5}$, and $\mathrm{NO}_{2}$ were significant at lag 0-7 and 0-14 days, whereas the cumulative effect of $\mathrm{PM}_{10}$ and $\mathrm{SO}_{2}$ was significant at lag 0-7 days.

The optimum RRs of daily confirmed COVID-19 cases with environmental factors were illustrated in Fig 3. The relative risk was variable by environmental factors. Mean temperature had the strongest negative effect on daily confirmed COVID-19 cases. $\mathrm{PM}_{2.5}, \mathrm{SO}_{2}, \mathrm{PM}_{10}$ and $\mathrm{NO}_{2}$ had significant positive effects on daily confirmed COVID-19 cases,while AQI showed the strongest positive relationships with daily confirmed COVID-19 cases

\section{Discussion}

In this study, we estimated the short-term association between COVID-19 and environmental factors in Shanghai. We found that the exposure-response relationship between COVID-19 and $\mathrm{T}_{\text {ave }}$ was positive when $\mathrm{T}<5{ }^{\circ} \mathrm{C}$ and became negative when $5{ }^{\circ} \mathrm{C}<\mathrm{T}<15^{\circ} \mathrm{C}$. Our findings that higher temperature may have a negative relationship with the transmission of COVID-19 are consistent with those of others (Del and Camacho-Ortiz 2020; Cole et al. 2020). Das et al. (2020) suggested that countries with low temperatures were more susceptible to infection than those with higher temperatures. A global study (Iqbal et al. 2020) revealed that countries with long and cold winters are at high risk for faster COVID-19 transmission, and the rate of spread would decrease when the weather becomes warmer. A study in China (Zhu and Xie 2020) reported a positive linear relationship between COVID-19 in the range of $\mathrm{T}<3{ }^{\circ} \mathrm{C}$, which became negative when $\mathrm{T}>3{ }^{\circ} \mathrm{C}$. A study in Brazil (Prata et al. 2020) indicated that the daily confirmed COVID-19 cases were significantly associated with a $-4.90 \%$ decrease per $1{ }^{\circ} \mathrm{C}$ increase in temperature. This result can be useful for policymakers, and countries with lower temperatures must adhere to quarantine policies and social distancing; the growth rate is predicted to decrease with control measures and warmer weather (Nazari et al. 2020; Kraemer et al. 2020).

Other meteorological elements also play an important role in the spread, growth, and survival of viruses (Lee 2003; Cai et al. 2007; Sahin 2020; Menebo 2020). Altamimi and Ahmed (2020) found that the incidence of MERS was significantly
Table 4 Generalized additive model test results between mean temperature, temperature humidity index, index of wind effect, air quality index, $\mathrm{PM}_{2.5}$, $\mathrm{PM}_{10}, \mathrm{NO}_{2}$, and $\mathrm{SO}_{2}$ and daily confirmed coronavirus disease 2019 cases

\begin{tabular}{lllllllll}
\hline & $\mathrm{T}$ & $\mathrm{THI}$ & $\mathrm{K}$ & $\mathrm{AQI}$ & $\mathrm{PM}_{2.5}$ & $\mathrm{PM}_{10}$ & $\mathrm{NO}_{2}$ & $\mathrm{SO}_{2}$ \\
\hline Edf & 1.948 & 1.916 & 1.025 & 1.262 & 2.26 & 2.856 & 2.04 & 2.856 \\
Ref.df & 2.176 & 1.993 & 1.010 & 1.343 & 2.896 & 2.987 & 2.434 & 2.984 \\
P-value & $<2 \mathrm{e}-16$ & 0.002 & 0.028 & 0.0002 & $<2 \mathrm{e}-6$ & $<0.004$ & $<0.007$ & $<8 \mathrm{e}-6$ \\
Adjusted R & 0.238 & 0.303 & 0.158 & 0.116 & 0.052 & 0.011 & 0.034 & 0.019 \\
Deviance explained & $31.1 \%$ & $36.4 \%$ & $22.2 \%$ & $13.1 \%$ & $7.8 \%$ & $4.7 \%$ & $4.8 \%$ & $6.7 \%$ \\
\hline
\end{tabular}



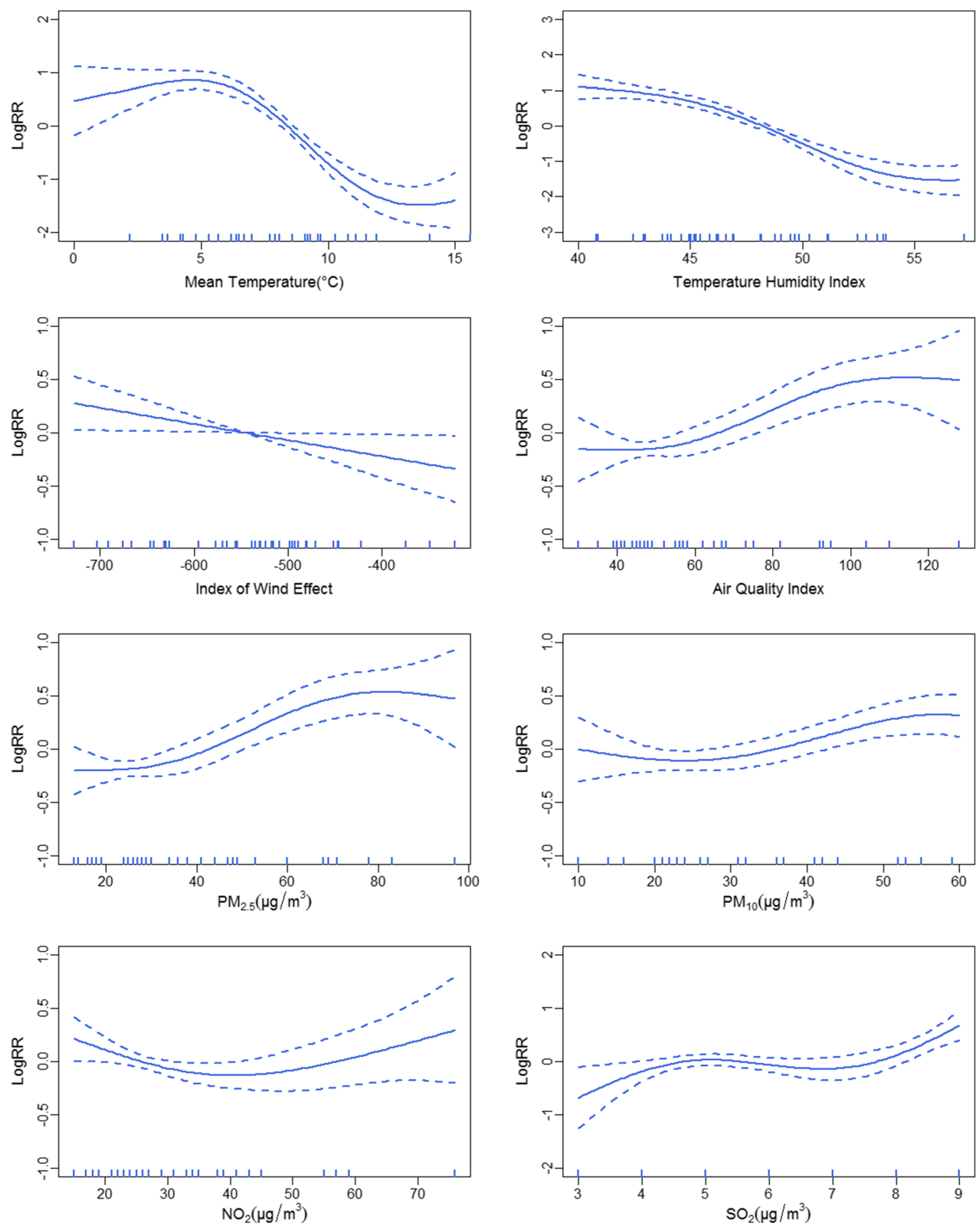

Fig. 1 Exposure-response relationship between mean temperature $\left(T_{\text {ave }}\right)$, temperature humidity index (THI), index of wind effect (K), air quality index (AQI), $\mathrm{PM}_{2.5}, \mathrm{PM}_{10}, \mathrm{NO}_{2}$, and $\mathrm{SO}_{2}$ and daily confirmed

associated with lower humidity (incidence rate ratio [IRR] = $0.956,95 \%$ CI: 0.948-0.964) and lower wind speed (IRR = 0.945, 95\% CI: 0.912-0.979) in Riyadh region. Casanova et al. (2010) reported that SARS-CoV had greater survival when humidity was low $(20 \%)$ or high $(80 \%)$, because envelope viruses containing lipid membranes can survive well at

coronavirus disease 2019 cases in Shanghai. The solid lines indicate the logarithm of relative risk (RR); the dotted lines show 95\% confidence intervals

lower humidity (Sobsey and Meschke 2003). Runkle et al. (2020) found a positive exposure-response relationship between humidity and the COVID-19 incidence rate. Atalan and Atalan (2020) indicated that relative humidity and wind speed played important roles in the COVID-19 outbreak in Italy. Pani et al. (2020) found that dew point was significantly 

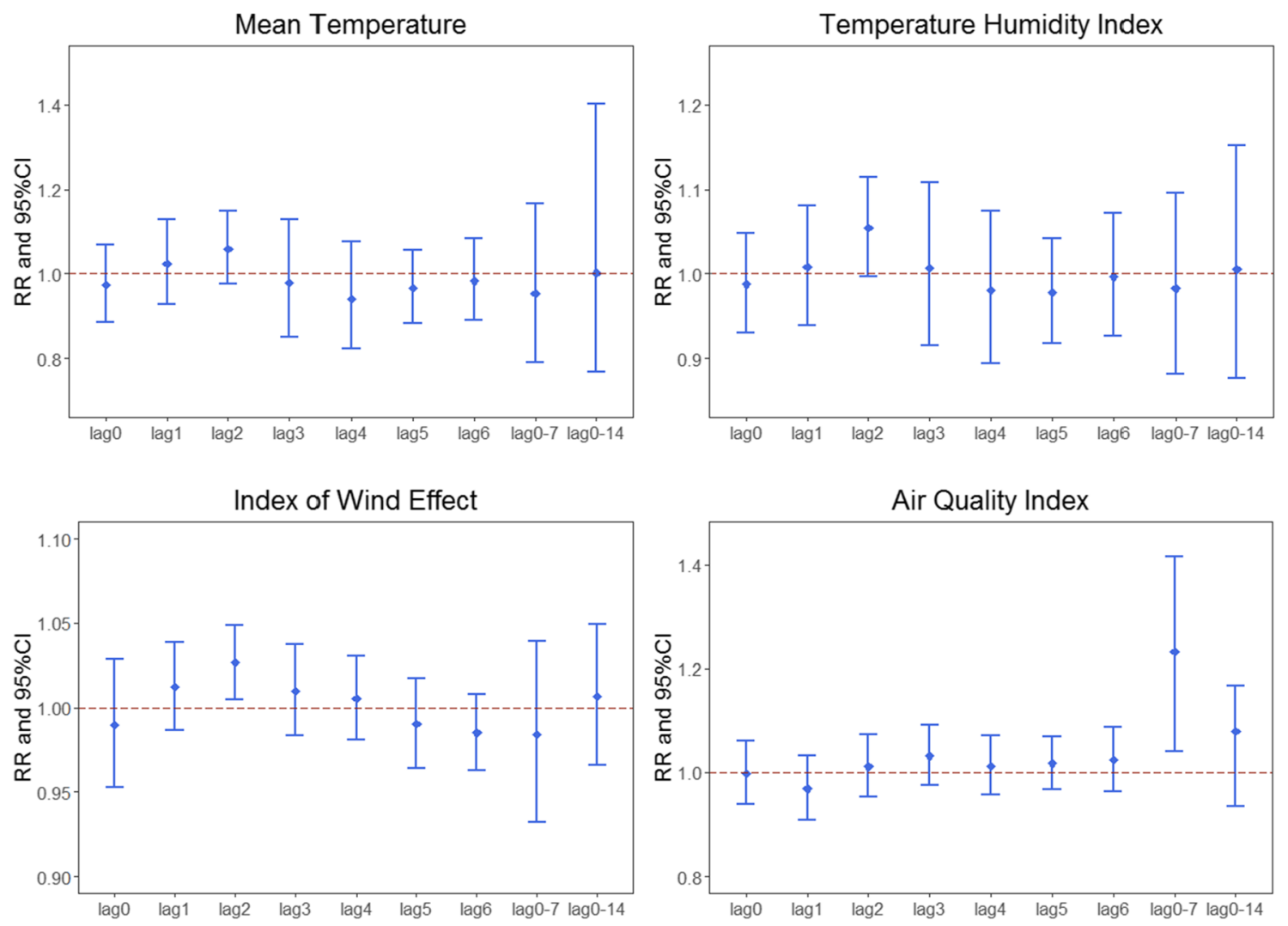

PM2.5
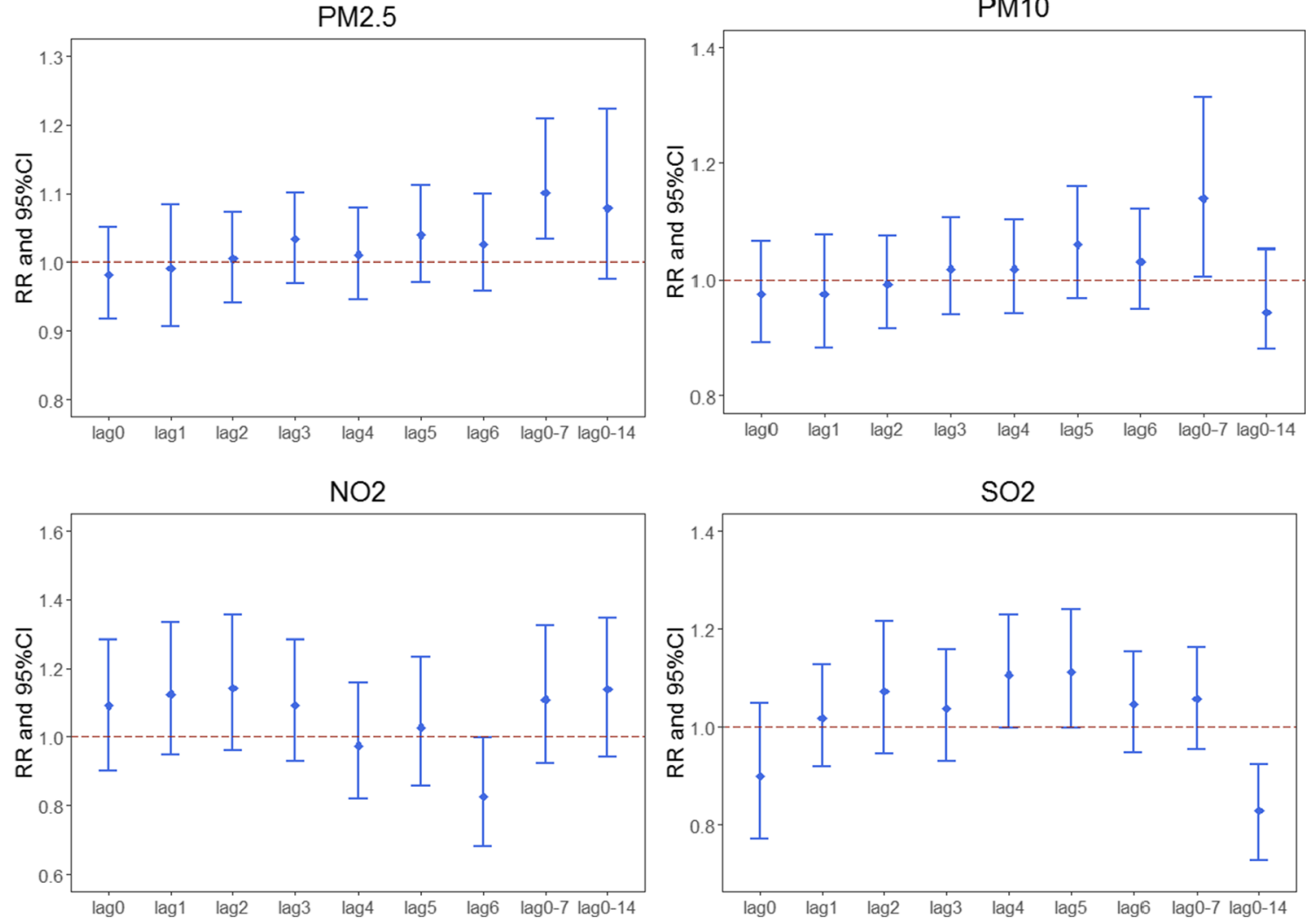

Fig. 2 Relative risk (RR) and cumulative RR (95\% confidence interval [CI]) of daily confirmed COVID-19 cases with a unit increase in mean temperature $\left(\mathrm{T}_{\mathrm{ave}}\right)$, temperature humidity index $(\mathrm{THI})$, index of wind

effect (K), air quality index (AQI), $\mathrm{PM}_{2.5}, \mathrm{PM}_{10}, \mathrm{NO}_{2}$, and $\mathrm{SO}_{2}$ in Shanghai. Units are $1{ }^{\circ} \mathrm{C}$ for $\mathrm{T}_{\text {ave }}, 1$ unit for THI, 10 units for $\mathrm{K}$ and AQI, $10 \mu \mathrm{g} / \mathrm{m}^{3}$ for $\mathrm{PM}_{2.5}, \mathrm{PM}_{10}$, and $\mathrm{NO}_{2}$, and $1 \mu \mathrm{g} / \mathrm{m}^{3}$ for $\mathrm{SO}_{2}$ 


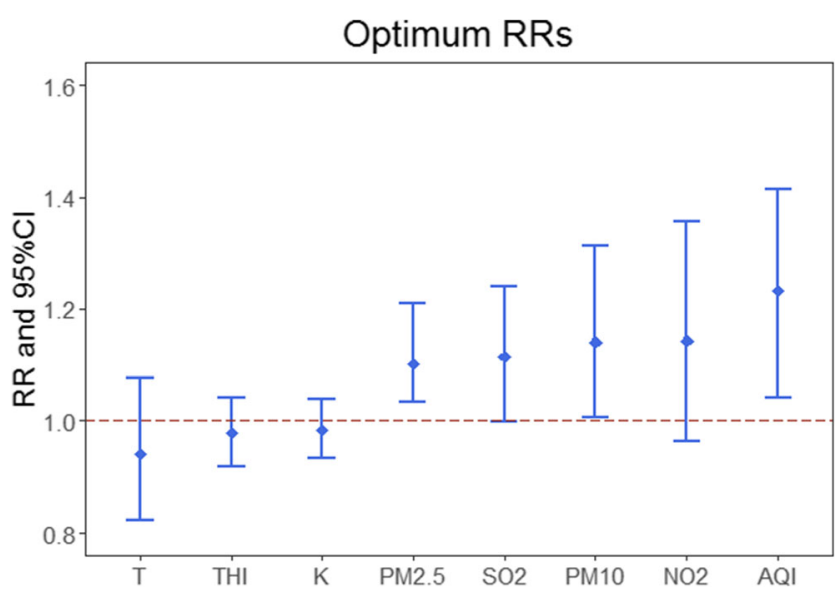

Fig. 3 Optimum RRs of daily confirmed COVID-19 cases with environmental factors

positively correlated with COVID-19 cases in Singapore. Silva et al. (2020) found that COVID-19 cases were negatively correlated with relative humidity, daily precipitation and wind speed in humid equatorial climate. In this study, we used two biometeorological indexes (THI and $\mathrm{K}$ ), which indicate the level of human thermal comfort, to estimate the combined effect of meteorological elements. The THI is determined through temperature and humidity and $\mathrm{K}$ through temperature and wind speed. A unit increase in the THI or a 10-unit increase in $\mathrm{K}$ was associated with a 1.8 or $1.6 \%$ decrease in daily confirmed COVID-19 cases, respectively, indicating that COVID-19 transmission rates may also have a negative relationship with humidity and wind speed.

Our findings revealed a significant positive association between air pollution and COVID-19. $\mathrm{NO}_{2}$ was an exception and had a weak effect on COVID-19 at a low concentration, whereas other pollutants had significant positive relationships with COVID-19. With a $10-\mu \mathrm{g} / \mathrm{m}^{3}$ increase in $\mathrm{PM}_{2.5}, \mathrm{PM}_{10}$, and $\mathrm{NO}_{2} ;$ a $1-\mu \mathrm{g} / \mathrm{m}^{3}$ increase in $\mathrm{SO}_{2}$; and a 10 -unit increase in the AQI, daily confirmed cases would have a $3.9 \%$ (lag 5 days), $6.0 \%$ (lag 5 days), 14.2\% (lag 2 days), 11.3\% (lag 5 days), and $2.3 \%$ (lag 6 days) increase, respectively. Studies have reported that air pollution is significantly associated with viruses (Dominici et al. 2006; Xu et al. 2013). Li et al. (2020) indicated that the COVID-19 incidence would increase with an increase in AQI, $\mathrm{NO}_{2}$, and $\mathrm{PM}_{2.5}$. A seasonal analysis (Liu et al. 2020a, b) using distributed lag non-linear model found that $\mathrm{PM}_{2.5}, \mathrm{SO}_{2}$, and $\mathrm{O}_{3}$ had significant cumulative effects on daily confirmed cases. Zhu et al. (2020) found that with a $10-\mu \mathrm{g} / \mathrm{m}^{3}$ increase in $\mathrm{PM}_{2.5}, \mathrm{PM}_{10}, \mathrm{O}_{3}$, and $\mathrm{NO}_{2}$, the daily confirmed cases would have a $2.24 \%$ (95\% CI: 1.02-3.46), $1.76 \%$ (95\% CI: $0.89-2.63), 4.76 \%$ (95\% CI: $1.99-7.52$ ), and 6.94\% (95\% CI: 2.38-11.51) increase, respectively. Lee et al. (2014) reported that air pollution may damage the human respiratory barrier and deposit in the respiratory tract and lungs, which facilitate viral attachment.
We have found that $\mathrm{T}_{\text {ave }}$, THI, K, AQI, $\mathrm{PM}_{2.5}, \mathrm{PM}_{10}, \mathrm{NO}_{2}$, and $\mathrm{SO}_{2}$ had lag and persistence effects on COVID-19. $\mathrm{T}_{\text {ave }}$, THI, $\mathrm{K}, \mathrm{PM}_{10}$, and $\mathrm{SO}_{2}$ had significant cumulative effects at lag 0-7 days, whereas the cumulative effects for AQI, $\mathrm{PM}_{2.5}$, and $\mathrm{NO}_{2}$ were significant at lag $0-7$ and $0-14$ days. A 10 unitincrease in $\mathrm{AQI}$ and a $10-\mu \mathrm{g} / \mathrm{m}^{3}$ increase in $\mathrm{PM}_{2.5}$ and $\mathrm{NO}_{2}$ were associated with $7.9 \%, 7.8 \%$, and $10.1 \%$ increase in daily confirmed cases at lag 0-14 days, respectively. The persistence of $\mathrm{PM}_{2.5}$ on COVID-19 lasted longer than that of $\mathrm{PM}_{10}$, which might be because $\mathrm{PM}_{2.5}$ is more easily absorbed by humans (Zhu et al. 2020). Lag and persistence may vary according to region based on meteorological elements, number of confirmed cases, control measures used, and medical facilities available (Shahzad et al. 2020; Lin et al. 2006; Del and Camacho-Ortiz 2020). A study in Saudi Arabia (Gardner et al. 2019) revealed that MERS cases were significantly associated with the lowest temperature and humidity at lag 8-10 days and with wind speed at lag 5-6 days. Xu et al. (2020a, b) found a significant association between daily confirmed COVID-19 cases and AQI at lag 1-3 days.

We found a significant association between confirmed COVID-19 cases and environmental factors, but several limitations of the study need to be addressed. First, our data excluded confirmed cases by gender or age; therefore, we were unable to conduct subgroup analysis. Second, our results are not generalizable because one city was enrolled in the study. Third, compared with other epidemiological studies, the study period was relatively short.

\section{Conclusion}

In this study, we used GAM to analyze the relationship between daily confirmed COVID-19 cases and environmental elements and found a significant negative association between daily confirmed COVID-19 cases and $\mathrm{T}_{\text {ave }}$, THI, and $\mathrm{K}$, while AQI, $\mathrm{PM}_{2.5}, \mathrm{PM}_{10}, \mathrm{NO}_{2}$, and $\mathrm{SO}_{2}$ were significantly associated with an increase in daily confirmed COVID-19 cases. And a significant lag and persistence were observed, $\mathrm{T}_{\mathrm{ave}}$, THI, $\mathrm{K}, \mathrm{PM}_{10}$, and $\mathrm{SO}_{2}$ had significant cumulative effect at lag 0-7 days, whereas AQI, $\mathrm{PM}_{2.5}$, and $\mathrm{NO}_{2}$ had significant cumulative effect at lag 0-7 and 0-14 days.

\section{Availability of data and material Data will be available on request}

Authors' contribution Yuxia Ma, Bowen Chen, conceptualization, methodology, writing and reviewing; JiaHui Shen, Hang Wang, software; Fengliu Feng, data curation; Yifan Zhang, Haoran Jiao, writingoriginal draft preparation.

Funding This research is supported by National Natural Science Foundation of China (Grant Nos. 41975141 and 41961028). Part of the 
work is funded by a Scholarship awarded to Yuxia Ma (File No. 20206185010) supported by the China Scholarship Council.

\section{Declarations}

Conflicts of interest The authors have no conflict of interest to declare.

Ethical approval This article does not contain any studies with human participants or animals performed by any of the authors.

Consent to participate Not applicable

Consent to publish Not applicable

\section{References}

Altamimi A, Ahmed AE (2020) Climate factors and incidence of Middle East respiratory syndrome coronavirus. J Infect Public Health 13(5): 704-708

Amuakwa-Mensah F, Marbuah G, Mubanga M (2017) Climate variability and infectious diseases nexus: Evidence from Sweden. Infect Dis Model 2(2):203-217

Atalan YA, Atalan A (2020) A Statistical analysis of the relationship between meteorological parameters and the spread of COVID-19 cases: comparison between Turkey and Italy. Appl Stat 1(2):76-84

Cai QC, Lu J, Xu QF, Guo Q, Xu DZ, Sun QW, Yang H, Zhao GM, Jiang QW (2007) Influence of meteorological factors and air pollution on the outbreak of severe acute respiratory syndrome. Public Health 121(4):258-265

Casanova LM, Jeon S, Rutala WA, Weber DJ, Sobsey MD (2010) Effects of air temperature and relative humidity on coronavirus survival on surfaces. Appl Environ Microbiol 76(9):2712-2717

Chen L, Yu J, He W et al (2020) Risk factors for death in 1859 subjects with COVID-19. Leukemia 34(8):2173-2183

Cole M, Ozgen C, Strobl E (2020) Air pollution exposure and COVID19. IZA Discussion Papers Series 13367

Das P, Manna S, Basak P (2020) Analyzing the effect of temperature on the outspread of COVID-19 around the Globe. medRxiv. https://doi. org/10.1101/2020.05.19.20107433

Del RC, Camacho-Ortiz A (2020) Will environmental changes in temperature affect the course of COVID-19? Braz J Infect Dis 24(3): 261-263

Dominici F, Peng RD, Bell ML, Pham L, McDermott A, Zeger SL, Samet JM (2006) Fine particulate air pollution and hospital admission for cardiovascular and respiratory diseases. Jama 295(10):1127-1134

Gardner EG, Kelton D, Poljak Z et al (2019) A case-crossover analysis of the impact of weather on primary cases of Middle East respiratory syndrome. BMC Infect Dis 19(1):1-10

Gunthe SS, Swain B, Patra SS et al (2020) On the global trends and spread of the COVID-19 outbreak: preliminary assessment of the potential relation between location-specific temperature and UV index. J Public Health 2020:1-10

Huang Z, Huang J, Gu Q, du P, Liang H, Dong Q (2020) Optimal temperature zone for the dispersal of COVID-19. Sci Total Environ 736: 139487

Iqbal MM, Abid I, Hussain S, Shahzad N, Waqas MS, Iqbal MJ (2020) The effects of regional climatic condition on the spread of COVID19 at global scale. Sci Total Environ 739:140101

Kraemer MUG, Yang CH, Gutierrez B, Wu CH, Klein B, Pigott DM, Open COVID-19 Data Working Group $\dagger$, du Plessis L, Faria NR, Li R, Hanage WP, Brownstein JS, Layan M, Vespignani A, Tian H, Dye C, Pybus OG, Scarpino SV (2020) The effect of human mobility and control measures on the COVID-19 epidemic in China. Science 368(6490):493-497

Lee SH (2003) The SARS epidemic in Hong Kong. J Epidemiol Community Health 57(9):652-654

Lee G, Saravia J, You D, Shrestha B, Jaligama S, Hebert V et al (2014) Exposure to combustion generated environmentally persistent free radicals enhances severity of influenza virus infection. Part Fibre Toxicol 11:57

Li H, Xu XL, Dai DW et al (2020) Air Pollution and temperature are associated with increased COVID-19 incidence: a time series study. Int J Infect Dis 97:278-282

Lin K, Fong DYT, Zhu B et al (2006) Environmental factors on the SARS epidemic: air temperature, passage of time and multiplicative effect of hospital infection. Epidemiol Infect 134(2):223-230

Liu Q, Sha D, Liu W et al (2020a) Spatiotemporal patterns of COVID-19 impact on human activities and environment in Mainland China using nighttime light and air quality data. Remote Sens 12(10):1576

Liu Q, Sha D, Liu W, Houser P, Zhang L, Hou R, Lan H, Flynn C, Lu M, $\mathrm{Hu}$ T, Yang C (2020b) Spatiotemporal patterns of COVID-19 impact on human activities and environment in mainland china using nighttime light and air quality data. Remote Sens 12(10):1576

Menebo MM (2020) Temperature and precipitation associate with Covid19 new daily cases: A correlation study between weather and Covid19 pandemic in Oslo, Norway. Sci Total Environ 737:139659

Mollalo A, Vahedi B, Rivera KM (2020) GIS-based spatial modeling of COVID-19 incidence rate in the continental United States. Sci Total Environ 728:138884

Nazari HN, Shirbandi K, Rahim F (2020) Environmental concern regarding the effect of humidity and temperature on SARS-COV-2 (COVID-19) survival: Fact or fiction. SSRN Electron J. https:// doi.org/10.2139/ssrn.3563403

Notari A (2021) Temperature dependence of COVID-19 transmission. Sci Total Environ 763:144390

Pani SK, Lin NH, RavindraBabu S (2020) Association of COVID-19 pandemic with meteorological parameters over Singapore. Sci Total Environ 740:140112

Peto J, Alwan NA, Godfrey KM, Burgess RA, Hunter DJ, Riboli E, Romer P, Buchan I, Colbourn T, Costelloe C, Davey Smith G, Elliott P, Ezzati M, Gilbert R, Gilthorpe MS, Foy R, Houlston R, Inskip H, Lawlor DA, Martineau AR, McGrath N, McCoy D, Mckee M, McPherson K, Orcutt M, Pankhania B, Pearce N, Peto R, Phillips A, Rahi J, Roderick P, Saxena S, Wilson A, Yao GL (2020) Universal weekly testing as the UK COVID-19 lockdown exit strategy. Lancet 395(10234):1420-1421

Prata DN, Rodrigues W, Bermejo PH (2020) Temperature significantly changes COVID-19 transmission in (sub) tropical cities of Brazil. Sci Total Environ 729:138862

Runkle JD, Sugg MM, Leeper RD, Leeper RD, Rao Y, Matthews JL, Rennie JJ (2020) Short-term effects of weather parameters on COVID-19 morbidity in select US citie. Sci Total Environ 740: 140093

Şahin M (2020) Impact of weather on COVID-19 pandemic in Turkey. Sci Total Environ 728:138810

Sarkodie SA, Owusu PA (2020) Global assessment of environment, health and economic impact of the novel coronavirus (COVID19). Environ Dev Sustain 2020:1-11

Shahzad F, Shahzad U, Fareed Z, Iqbal N, Hashmi SH, Ahmad F (2020) Asymmetric nexus between temperature and COVID-19 in the top ten affected provinces of China: A current application of quantileon-quantile approach. Sci Total Environ 736:139115

Silva FL, Gomes MDA, Silva APL et al (2020) Correlation between meteorological factors and COVID-19 infection in the Belem Metropolitan Region. medRxiv. https://doi.org/10.1101/2020.06. 10.20127506 
Sobsey MD, Meschke JS (2003) Virus survival in the environment with special attention to survival in sewage droplets and other environmental media of fecal or respiratory origin. WHO 70:19-39

Sohrabi C, Alsafi Z, O'Neill N et al (2020) World Health Organization declares global emergency: A review of the 2019 novel coronavirus (COVID-19). Int J Surg 76:71-76

Waldman G, Mayeux R, Claassen J, Agarwal S, Willey J, Anderson E, Punzalan P, Lichtcsien R, Bell M, Przedborski S, Ulane C, Roberts K, Williams O, Lassman AB, Lennihan L, Thakur KT (2020) Preparing a neurology department for SARS-CoV-2 (COVID-19): Early experiences at Columbia University Irving Medical Center and the New York Presbyterian Hospital in New York City. Neurology 94(20):886-891

Xu Z, Hu W, Williams G, Clements ACA, Kan H, Tong S (2013) Air pollution, temperature and pediatric influenza in Brisbane, Australia. Environ Int 59:384-388

Xu Z, Shi L, Wang Y, Zhang J, Huang L, Zhang C, Liu S, Zhao P, Liu H, Zhu L, Tai Y, Bai C, Gao T, Song J, Xia P, Dong J, Zhao J, Wang FS (2020a) Pathological findings of COVID-19 associated with acute respiratory distress syndrome. Lancet Respir Med 8(4):420 422

Xu H, Yan C, Fu Q, Xiao K, Yu Y, Han D, Wang W, Cheng J (2020b) Possible environmental effects on the spread of COVID-19 in China. Sci Total Environ 731:139211

Yan W, Yi WU, Jiang Z (2009) The tourism climate evaluation of Hubei province. Journal of Huazhong Normal University. https://doi.org/ 10.1016/S1003-6326(09)60084-4

Zhu Y, Xie J (2020) Association between ambient temperature and COVID-19 infection in 122 cities from China. Sci Total Environ $724: 138201$

Zhu Y, Xie J, Huang F, Cao L (2020) Association between short-term exposure to air pollution and COVID-19 infection: Evidence from China. Sci Total Environ 727:138704

Publisher's note Springer Nature remains neutral with regard to jurisdictional claims in published maps and institutional affiliations. 